УДК 821.161 .2

Бровко О. О., доктор філологічних наук, професор, завідувач кафедри української літератури і компаративістики, Київський університет імені Бориса Грінченка

\title{
ПОЛІФОНІЯ СУЧАСНОЇ УКРАЇНСЬКОЇ ЕПІКИ: ТРАДИЦІЯ І ДЕКОНСТРУКЦІЯ
}

Стаття присвячена аналізу поліфонії в сучасному прозовому творі. У дослідженні розглядаються внутрішні жанрові можливості, які містить новела як мала епічна форма, 
та вияви позажанрових зв'язків у творах Тараса Прохаська «НепрОсті», Василя Слапчука «Осінь за щокою», Сергія Жадана «Ворошиловград», Артема Чеха "Анатомічний атлас. Важко бути жабою».

Ключові слова: поліфонія, новела, структура, роман, проза, поетика, традиція, деконструкиія.

Статья посвящена анализу полифонии в современном прозаическом произведении. В исследовании рассматриваются внутренние жанровые возможности, которые содержит новелла как малая эпическая форма, и проявления внежанровых связей в произведениях «НепрОстые» Тараса Прохасько, «Осень за щекой» Василия Слапчука, «Ворошиловград» Сергея Жадана, «Анатомический атлас. Трудно быть жабой» Артема Yexa.

Ключевые слова: полифония, структура, роман, проза, поэтика, традиция, деконструкичия.

The article deals with the analysis of polyphony in modern prose work. Intragenre possibilities of short story as a small epic form and result of nongenre recations are examined in the investigation in works of "NeprOsti» by Taras Prokhasko, "Osin' za shhokoyu» by Vasyl Slapchuk, "Voroshylovgrad» by Serhij Zhadan, "Anatomichnyj atlas. Vazhko buty zhaboyu» by Artem Chekh.

Key words: polyphony, structure, novel, prose, poetics, tradition, deconstruction.

Початок розширення поняття «текст» пов'язаний iз науковими здобутками М. Бахтіна, якому належить дефініція діалогічності й текстового поліфонізму. Розвиваючи ці ідеї, Ю. Крістева й Р. Барт обгрунтовують тезу про інтертекстуальну природу будь-якого дискурсу, актуалізовану в сучасній літературі. Метою статті $\epsilon$ окреслення специфіки поліфонічної організації текстів сучасної української прози на матеріалі творчості Т. Прохаська, В. Слапчука, С. Жадана, А. Чеха.

Прикладом паралельного розміщення кількох інформаційних ліній $є$ проза Т. Прохаська. І. Дегтярьова відзначає, що в романі «НепрОсті» «у дужках автор помістив історію героїні, ї̈ батьків на двох сторінках, повчання, філософські, життєві істини, висловлювані іншими героями (Треба чути голос. Голос живий $і$ голос оживлює. Голос сильніший від образу... є речі, значно важливіші від долі. Скажімо, інтонащиї, синтаксис)» [Дегтярьова 2009:33]. Події в «НепрОстих» розгортаються між 1913 і 1951 роками. «Чому завжди війна?» - ця фраза 3 роману знову повертає увагу читача до думки про циклічність буття і запитань «що було, якби...?». Якби перемогла Карпатська Україна, якби державність спочатку утвердилася в Ялівці - українському острівці Центральної Свропи. «Моє місие завжди опинятиметься в центрі 
європейської історії, бо в цүих краях історія у різних формах сама приходить на наші подвір'я» [Прохасько 2006]. У цьому романі-есе уважний читач помітить зв’язок зі світовою мистецькою традицією магічного реалізму, українською химерною прозою. Художньою домінантою твору є жанрово-стильові маркери новонародженого канону літературної історичної альтернативістики, риси новоміфологізму або т. зв. «ландшафтного письма». Попри позірну моновекторність оцінок, означені риси свідчать про множинність інтерпретацій, глибину підтексту цієї художньої знахідки, що захоплює читача 3 перших сторінок і тримає запитанням «що буде далі?», відсилає до принципу циклічного руху міфологічної оповіді - історії містечка Ялівця, в якому химерно переплітаються цивілізаційні і культурні, рустикальні і модерні коди. Архаїка, яка зберігається у згадках про «непростих» чи «земних богів», здатна оновлюватися, актуалізуючи національні версії світової міфології. Текст Т. Прохаська вирізняється увагою до міфологізації свідомості, адже наративні версії різних сценаріїв української історії засвідчують потребу сучасної людини осмислити минуле своєї країни. Персонажі одночасно перебувають у подієвому світі, змальованому у творі, та міфологічному, що становить глибинний зміст оповіді i накладається на актуальний сюжет - формування національної ідентичності на території помежів'я, бо центральноєвропейський курорт Ялівець «знаходився в Українських Kарпатах, а не просто в Чехо-Словаџькій республіці. Але Станиславів, Львів і Арджелюджа опинилися за забороненою лінією на Чорногорі» [Прохасько 2006]. Образ Українських Карпат в художньому світі Т. Прохаська сприймається як модель світоустрою, що тримається на осерді - власній ідентичності як умові існування впорядкованого світу i як альтернативному націєтворчому чинникові: «Українська держава можлива лише тоді, коли карпатський вектор стане основою ї̈ геополітики, карпатська космогонія - моделлю ідеологї̈, а самі Карпати - природним резерватом» [Прохасько 2006]. Основний топос цього роману-есе місто-дерево, місто-химера, де переплітаються, повторюючись, життя, де формується нова історіософія. Для героя роману й оповідача повернення в 
Ялівець, вибудуваний зі слів і думок, - це своєрідна дорожня карта митця як модель відкритої ним території. «Коли воює Південь з Північчю, а Схід із Заходом, то роблять цฺе переважно в Центральній Свропі, де Карпати $і$ їхні річки. I найгірме, щзо може бути в такі часи, - виконувати роль мирного населення Kарпат або стратегічно важливого пункту на півкілометровій mопографічній мапі» [Прохасько 2006]. Як бачимо, картографічні відмінності в семіотичному, вербальному сенсі від географічного світу як території («Карта не є територія» А. Коржибськи, «Карта перечитування» Г. Блума) інспірують актуальну реконструкцію і перевизначення ідентичності як проблеми.

Художній поліфонізм характеризує поетику ще одного сучасного автора В. Слапчука. Роман «Осінь за щокою», написаний упродовж 1995-2004 років, поєднує спогади, рефлексії, голоси інших, на що звертали увагу Є. Баран, I. Бондар-Терещенко, А. Тихонова, М. Зайдель та інші літературні критики. Цілісності тексту надає внутрішня композиція, яка підводить читача до розв’язки-пояснення в останній новелі. Композиційно роман складається 3 восьми частин, жанрові особливості яких позначені аморфністю, адже вони мають ознаки новел і літературної есеїстики. Монтажна композиція посилює дискретність зображення, окремі фрагменти поетичних, оповідних i драматургічних текстів об’єднані навколо кількох провідних образів - жінка, дощ, ім’я. Ці образи актуалізуються в кожній частині роману, набуваючи нових нюансів. Перша частина «Четвер» відсилає читача до витоків людської поведінки, хоча сам автор двічі згадує батька психоаналізу в іронічному контексті: «Очевидно, тут попахувало фройдятиною. Шлях би того Фройда трафив [Слапчук 2009:238]; «Для діда Фройда роботи - непочатий край» [Слапчук 2009:132]. Чорні (чи чорнильні?) слова матері на пелюшках майбутнього письменника; сварка 3 приводу імені новонародженої дитини; дід, який консервує людський дух у слоїки, - світ, де Чоловікові ніхто «ніколи не подарує маленького сонцяя» [Слапчук 2009:8]. Письменник Арсен Кіриєнко втомився від війни, від людей, від поезії, від самотності, від життя й від смерті. «Втома воїна» сповнена посилань на тексти попередників. Оригінальним 
композиційним прийомом $\epsilon$ введення багатоголосся (жіночий, чоловічий, зляканий, оптимістичний, допитливий, песимістичний, голос із комина). Читач знаходить діалог із Ф. Ніцше: «Заратустра казав, щзо чоловіка треба виховувати для війни, а жінку - для відпочинку воӥна. Сам він, очевидно, ніколи не був на війні і не мав жінки» [Слапчук 2009:51]; «Війна скидається на секс. На війні чоловіки доводять собі (у першу чергу собі) та жінкам, щзо вони мужчини. Що вони можуть. На війні легше самоствердитись, аніж у ліжку 3 жінкою. Тому чоловіки вибирають війну. Воякові не потрібне ім'я, достатньо номера, позивного або ж звання» [Слапчук 2009:36]. Концептуальним є ставлення до тексту попередника через прозовий переказ відомої поезії: «Ще вчора я повторював ім'я однієї зорі, бо з іншими мені було темно. Я молився на неї не тому, щзо вона мені світила, а тому, щзо з нею не потребував світла...

Ти пропонуєи спалити томик Інокентія Аненського?

- Я пропоную спалити все. Звільнитися $і$ дати волю, відчути спокій... Хіба ти не любии спостерігати за полум'ям?» [Слапчук 2009:17].

Багатогранність ліричного персонажа, який перебуває на межі розщеплення психіки, найвиразніше розкривається через сни, уявні й написані художні тексти, а також через спілкування 3 жінками: «Хmо я? Kumaєu̧ь? Метелик? Чи син своєї матері? Хто кому сниться?.. Я - чорне дерево гіллясте. В рожевих птахів хтось стріляв - додолу падають з гілля, а я ніяк не можу впасти. Не можу впасти, ані вмерти... Поль Елюар переконаний, щзо можна померти від того, щзо не помираєщ. Елюар був поетом. Дивно, щзо він дожив до cmaрості, а не заподіяв собі смерть» [Слапчук 2009:34]. Поєднання сюжетної лінії головного героя 3 фрагментами розповідей про його персонажів увиразнюється в частині «Мандрівка на рожевому дирижаблі», де показано взаємини письменника й Коли, Ого й дівчини, Кіра і його дружини Тетяни. Автор пояснює, що Кір - це Ого через кілька років, проте жінки часто плутають художній вимисел із реальністю. У думках Кір звертається то до Свангелія, то до В. Набокова, то до К. Малевича: «Зиркнув у бік вікна. Замислився, наче перед «Чорним квадратом Малевича. Втім, хіба чорний квадрат - не фрагмент 
шкільної дошки, ретельно витертої перед уроком? Тільки ж суть зосталося на ганчірочиі, а ганчірочка - у руиі чергового...» [Слапчук 2009:100]. Головний герой новели «Потяг над містом» I Ван спостерігає, як віддаляється жінка 3 потягу, на який він не встиг. У цій частині постає яскрава художня деталь, своєрідний інтертекстуальний маркер - срібна чорнильниця Чехова, яку письменник ставить для натхнення поруч із комп'ютером. У наступних розділах читач знаходить цитати поезій самого автора, згадки про Г. Флобера, М. Павича, М. Басьо, визначення віку співрозмовників через порівняння 3 тривалістю життя М. Лермонтова й А. Рембо. Письменник спалює свій рукопис, знаходить у комп'ютері файл, названий жіночим ім'ям, - одне 3 перших своїх оповідань, натискає Delete: «Любив книги й жінок. Книги - трохи більше. За книги я платив. Я їх хотів. Жінки ж були. Вони мені не заважали. Крізь них я міг дивитись у своє вікно. А через вікно - на них» [Слапчук 2009:249].

«Осінь за щокою»- це поліфонічний синтез наведених подій з іншими діями розповідача й фрагментами творів ліричного героя. Остання частина роману, названа «Табурет, прибитий до підлоги», розкриває всі загадки твору, адже письменник потрапляє до в'язниці чи то за зберігання зброї, чи за зберігання наркотиків і бачить різні паспорти зі своӥми фото: «Оией виписаний на ім'я Арсена Кіриєнка, цей - на Григорія Олійника, цей - на I Ван Сина... У чоловіка підкосилися ноги.

- Це чийсь лихий жарт, - витер долонею враз спітніле чоло. - Я не знаю, як ие пояснити... Справа в тому, що я - письменник... Якісь із изих імен - мої псевдоніми, інші - імена героїв мойх творів...» [Слапчук 2009:275]. Отже, «двійник присвоює тон голосу персонажа, зобов'язуючи його впізнати себе, свою ідею і своє слово, впізнати автентичного себе, яким він був колись. Так «я» перетворюється в «мого» двійника, «тут»- в «там», «тепер»- в «колись». Інший світ, утворений за допомогою дзеркала, дає змогу знову знайти своє справжнє, колись загублене «я», злитися 3 ним» [Агранович 2001:142]. У романі мотив письменницької праці є іманентно цікавим, водночас, через 
того, хто пише, реалізується віртуальна можливість тексту. Аналогічні художні прийоми поширені у світовій літературі останніх десятиліть. Наприклад, «Зоряна мантія М. Павича складається із новостворених астрологічних коментарів. Автор подає глибоко інтимізовані, щирі розповіді в дискурсивній практиці чоловічого й жіночого текстів, але в останній структурній частині гендерний аспект поступається перед політичним. Дискретність зображення, монтажність композиції надають поетиці «Зоряної мантії» рис витвору кіномистецтва 3 його спрямованістю на семантику можливих світів [Павич 2002].

Завдяки книжці «Історія і занепад джазу в Донецькому басейні» в романі С. Жадана «Ворошиловград» розгортається авантюрно-детективна новелістична сюжетна лінія [Жадан 2010:369]. Набір листівок з пам’ятками і краєвидами міста як симулякр тієї реальності, що на них відображена, міста, назви якого немає, асоціативно пов’язаний із містифікованою історією джазу на Донбасі та розповіддю про зникнення Глорії. «Ворошиловграда немає, а ми $\epsilon,-$ говорить Ольга. Після зниклої співачки залишилися рукописи музичних творів, численні ліричні й соціально-суголосні зразки джазового хорового співу, що «неодноразово виконувались всесвітньовідомими джазменами, такими як Чесні Генрі Бейкер або Чарльз Бьорд Паркер» [Жадан 2010:381]. Поданий далі спірчуел-псалом, названий одним із останніх творів, написаних Глорією Абрамз, можна вважати емоційною кульмінацією роману: «Ми згадуємо, Господи, намі міста, й плачемо за ними. / Ми вішаємо на деревах наші гітари й труби, і заходимо в ріку. / Стоячи в теплих хвилях, ми співаємо вслід зеленій воді, / щуо протікає повз нас. / Стоячи серед теплих хвиль, ми співаємо вслід життю, / щзо витікає крізь пальи̧і [Жадан 2010:381].

Уведення новелістичних наративів поширене в прозі молодих авторів («Поклоніння ящірці» Л. Дереша, «Анатомічний атлас» А. Чеха та ін.). Так, роман А. Чеха «Анатомічний атлас. Важко бути жабою (2008) - це, як зазначено в анотації, «анатомія больових точок» покоління автора. У стилістиці, притаманній значній частині письменників сьогодення, А. Чех 
торкається традиційних для літератури питань самотності, людської байдужості, вибору, пошуків щастя; змальовує життя вчорашніх підлітків, у якому нерозуміння батьків, байдужість учителів, алкоголізм, наркоманія, психлікарня, проституція й навіть самогубство та вбивство стають жахливими, але водночас, буденними явищами. Елементи некодифікованого мовлення, введені в діалоги персонажів та авторські відступи, увиразнюють ситуацію безперспективності й відчаю, наприклад, в 11-й главі IV частини, де в напівмаренні герой-оповідач розмірковує, ким міг би стати Вій - лауреат уявних Нобелівських премій. Роман «Анатомічний атлас». Важко бути жабою», певною мірою, за тематикою близький до «Пациків» А. Дністрового, «Anarchy in the UKR» С. Жадана, низки творів Ю. Покальчука («Вертеп», «Окружна дорога», «Хуліган Зайчик», «Мама Рома і пацани», «Таксі-блюз» тощо), а також інших книжок А. Чеха - «Цього ви не знайдете в Яндексі», «Doc $1 »$, «Пластик», «Сині двері зліва». Жанр твору «Анатомічний атлас. Важко бути жабою» вмотивовано декларований як «пацаняча антиутопія». В утопічності сподівань героїв на щастя, ілюзорності їхніх мрій відбито реалії нашого сьогодення: «I тільки тюльпани стоятимуть на підвіконні у вазі з австрійського скла, знаменуючи велику трагедію в сім $\dddot{l}$ Сорбсен, а також спогад про велику жабу дитячої літератури Віталіка Ромашина, і весь світ наповниться співчуттям до Герті ци вилікується від усіх хвороб, адже проллється світло до їхніх організмів, а згодом людство скасує інститут війни, i настане тотальне щзастя і непорушний мир, $і$ всі люди гладитимуть левів та жирафів, французи посміхатимуться арабам та неграм, а гої, на знак пошани до євреїв, не їстимуть свинину, а лище стиглі яблука та шовковицю з садів Господніх» [Чех 2008:175]. Схожий емоційний стан переживає героїня роману Ірен Роздобудько «Гудзик». Ліка нагадує химерного Ієланума 3 розповіді Ганни Тарасівни: «... Ім'я його - вітер у полі, ім'я - виття, в якому більше сенсу, ніж у людських балачках. Ієланум не любить слів $і$ ніколи не знайде співрозмовника. Слова - n’явки, щуо наповнюють рот гіркотою. Ієланума виштовхали у світ, $i$ світ не прийняв його. <..> Ієланум є світлом світла і темрявою темряви: ні 
там, ні там його не впіймати. Ієланум - той, хто збожеволів за власним бажанням [Роздобудько 2006:183]. Зв’язки цих фрагментів свідчать про взаємопроникнення основного й елективного текстів, адже ризоматика як посутній принцип постмодерної естетики знайшов практичне втілення в конструктах кінця XX - початку XXI ст. Але в романі А. Чеха вільна гра 3 біблійним матеріалом у вставній новелі, вміщеній у цьому ж IV-му розділі під назвою «Стара, як світ, єврейська притча», не відзначається художньою переконливістю й естетико-змістовою доцільністю. Притча подається 3 імпліцитним обрамленням, 3 традиційною оповіддю іiі пов’язує лише зачин «Жив-був старий дід Ієгуда» [Чех 2008:156], а маркером гри з біблійним текстом $є$ порівняння, вміщене в останньому реченні попередньої глави: «...відповідальність за життя твого друга, який піниться $і$ трясеться, неначе осиковий прапор на серпневому Майдані, чи щзось типу того» [Чех 2008:155]. «Знову згадаємо про особливість постмодерністського стилю стирання психологічних кордонів у сприйнятті вербальної інформації та мистецтва взагалі - немає первинних чи вторинних за значенням та вагою мовних одиниць, адже важливим є абсолютно все», - наголошує І. Дегтярьова [Дегтярьова 2008:33]. Проблема вибору й гріховності розгортається в тексті через поширений мотив боротьби за людську душу: «У давніх єврейських сказаннях йдеться про те, щзо коли людина згрішила і переклала провину на інші плечі, то темний архангел фіксував цей гріх, і потім десь там тобі нагадають про нього вилами та кип'яченою смолою, але коли людина взяла відповідальність на себе і погодилась, щзо у иььому разі винна саме вона, людина, i ніхто інший, то цуе автоматично очищуало ї̈ карму» [Чех 2008:157]. Для Темного архангела Біни Цафкіеля й світлого архангела Хохми Раціеля метою стає старий єврей, який вірив у дива, але продовжував грішити i не дотримуватись писань Тори. «-Що, друже, - грізно глянув на нього Господь, хотів стражданням купити вічну гармонію? Не вийде. Малі твої муки. Ти скотолозтвом займався, перелюбством, ти свинину жер, щуосуботи працював, та й твоя відмова була нещчирою. Не буде тобі прощуення. I дарма ти не 
погодився вступити з Люцифрером у згоду. Він би тобі приніс щяастя» [Чех 2008:159]. Авторське трактування цього біблійного мотиву суголосне психологічному стану й життєвим ситуаціям героїв «пацанячої антиутопії»: «Коли Ієгуду спровадили до пекла, сів Бог на ослін та й задумався. Ох, думав він, не люблю я, коли душею кривлять та не знати чого хочуть. Неприємно це все. Неприємно...» [Чех 2008:159]. I. Набитович зауважує: «У прозі Ю. Винничука та Любка Дереша, як видається, гротескова трансформачія сакрального, постмодерна гра з сакральними символами в еротичних дискурсивних стратегіях несе на собі печаль обездуховлення й мертвотности людини ареліzійної» [Набитович 2008:490]. Подібна деконструкція релігійно маркованих концептів спостерігається і в цьому романі А. Чеха.

Отже, поліфонія реалізується на рівні творення множинних світів, внутрішньої організації художнього мовлення, інтертекстуальних зв'язків, трансформації жанрових форм. Нонселекція, фрагментарність, ризоматика сучасної епіки, розмаїття новелістичних конструктів у структурі українського роману відкривають простір для подальшого дослідження.

\section{БІБЛІОГРАФІЯ}

Агранович 2001 - Агранович С. 3. Двойничество / С. 3. Агранович, И. В. Саморукова. - Самара : Изд-во «Самар. ун-т», 2001. - 132 с.

Дегтярьова 2009 - Дегтярьова I. Стилістичний синтаксис української постмодерністської прози / Ірина Дегтярьова // Українська мова. - 2009. № 3. - C. 27-38.

Жадан 2010 - Жадан С. Ворошиловград : [роман] / Сергій Жадан. - Х. : Фоліо, 2010. - 447 c.

Набитович 2008 - Набитович I. Універсум sacrum'у в художній прозі (від Модернізму до Постмодернізму) : [монографія]. - Дрогобич - Люблін : Посвіт, 2008. $-600 \mathrm{c}$.

Павич М. Зоряна мантія : астрологічний путівник для невтаємнивчених / Мілорад Павич ; [пер. з серб Алла Татаренко]. - Л. : ВНТЛ-Класика, 2002. $120 \mathrm{c}$. 
Прохасько 2006 - Прохасько Т. НепрОсті [Електронний ресурс] / Тарас Прохасько. - Івано-Франківськ : Лілея-НВ, 2006. - 140 с. - Режим доступу : http://www.azh.com.ua/lib/taras-prokhasko-neprosti.

Роздобудько 2006 - Роздобудько I. Гудзик [психологічна драма] / Ірен Роздобудько. - Х. : Фоліо, 2006. - 222 с.

Слапчук 2006 - Слапчук В. Осінь за щокою : [роман] / Василь Дмитрович Слапчук. - К. : Факт, 2006. - 277 с. - (Серія «Exceptis excipiendis»).

Чех 2008 - Чех А. Анатомічний атлас. Важко бути жабою : [роман] / Артем Чех. - Х. : Фоліо, 2008. - 187 с. 